\title{
Biomass-diversity relations of epiphytic bryophytes on small Quercus copeyensis stems in a Costa Rican montane cloud forest
}

\author{
H.J.F. Van Dunné1 and M. Kappelle 1,2
}

1 University of Amsterdam, Hugo de Vries Laboratory, Kruislaan 318, 1098 SM Amsterdam, The Netherlands.

2 Present address: INBio, apartado postal 22-3100, Sto. Domingo, Heredia, Costa Rica.

Received 18-IV-1997. Corrected 23-I-1998. Accepted 18-II-1998

\begin{abstract}
Resumen: Se muestreó briófitas epífitas sobre tallos pequeños de Quercus copeyensis Müll. en un bosque montano nuboso maduro (Talamanca, Costa Rica). Se muestreó a 0.8-1.8 m en cinco tallos (d.a.p. 1.8 -2.8 cm), hallándose 22 especies de musgos y 22 de hepáticas. La biomasa de briófitas ("briomasa") se correlacionó con la frecuencia, contribuyendo los musgos 54-99\%. Un 14\% de las especies contribuyó casi el $90 \%$ de la briomasa, sobresaliendo Pilotrichella flexilis (Hedw.) Ångstr., Rigodium sp. 1, Porotrichodendron superbum (Taylor) Broth., Prionodon densus (Hedw.) Müll. Hal., Neckera chilensis Schimp. ex Mont. y Plagiochila guilleminiana Nees \& Mont. Estas especies podrían jugar un papel importante en la regulación del flujo de agua.
\end{abstract}

Key words: Biomass, bryophytes, Costa Rica, hydrology, montane cloud forest, mosses, Quercus.

Epiphytic bryophytes are an important structural feature of tropical montane cloud forests, where they play an important role in rainfall interception (Pócs 1980, Veneklaas and Van Ek 1990). They also have a significant capability of nutrient retention (Nadkarni 1986, Hofstede et al. 1993), affecting nutrient cycling within forests (Coxson 1990). Furthermore, they provide shelter for numerous small invertebrates (Gradstein 1992). Epiphytic biomass in tropical montane forests has been estimated on several tons per hectare for tropical montane forests (e.g. Pócs 1980, Nadkarni 1984). Other studies give an indication of epiphyte abundance, and especially of epiphytic bryophytes, in biomass per unit area, usually in $\mathrm{g}$ dry weight per $\mathrm{dm}^{2}$ (e.g. Frahm 1987, Veneklaas et al. 1990, Wolf 1993a, 1993b).
However, at present little information is available on biomass-diversity relations among epiphytic bryophytes on small stems in the understory of tropical montane cloud forests (Wolf 1993a). Thus, patterns of bryophyte biomass (bryomass) distribution were studied among epiphytic mosses and liverworts growing on small stems of a common oak tree species in a Costa Rican montane cloud forest. Implications of bryomass-diversity relations for conservation and management of tropical montane cloud forests are discussed.

This study was carried out in a mature, undisturbed upper montane Quercus copeyensis Müll. dominated cloud forest stand on the Pacific slope of the Cordillera de Talamanca in Costa Rica. A 0.05 ha forest plot $(20 \times 25 \mathrm{~m}$; SES aspect) was sampled at ca. $3000 \mathrm{~m}$ 
elevation near San Gerardo de Dota in the eastern corner of the Los Santos Forest Reserve $\left(9^{\circ} 35^{\prime} 40^{\prime \prime} \mathrm{N} ; 8^{\circ} 44^{\prime} 30^{\prime \prime}\right)$. In Villa Mills, at a distance of $10 \mathrm{~km} \mathrm{~W}$ of the selected forest plot, the average annual temperature is $10.9^{\circ} \mathrm{C}$ and the average annual rainfall is $2812 \mathrm{~mm}$ (Kappelle 1992). According to Kappelle (1996) this upper montane cloud forest is exclusively dominated by 30 to $35 \mathrm{~m}$ tall Quercus copeyensis and $Q$. costaricensis canopy trees, in association with Magnolia sororum, Schefflera rodriguesiana and Weinmannia pinnata. Numerous arborescent genera determine the aspect of the subcanopy, e.g. Ardisia, Comarostaphylis, Cornus, Ilex, Ocotea, Oreopanax, Styrax, Symplocos, Vaccinium, Viburnum and Zanthoxylum. The understory is dominated by Chusquea bamboos. The fern Elaphoglossum was particularly abundant at the forest floor of the selected plot.

In August 1992 a $2.5 \mathrm{~m}$ wide belt transect was laid out along the length axis of the the selected forest plot using a rope. Epiphytic bryophytes were sampled on each Quercus copeyensis stem within a distance of $1.25 \mathrm{~m}$ of the rope. Only stems of $Q$. copeyensis were selected in order to avoid differences in host specificity and bark properties. Samples were taken from the bark of stems covering the height interval between 0.8 and $1.8 \mathrm{~m}$ above soil level. A lower height of $0.80 \mathrm{~m}$ was selected to avoid bottom-up water and nutrient fluxes as a result from splashing at soil level during heavy rain fall. Only the west-facing bark of stems was sampled in order to avoid the strong influence of polarity on epiphytic bryophytes, such as caused by wind and horizontal precipitation ( $c f$. Barkman 1958: 40). For the present analysis a subset of five small stems with a dbh (diameter at breast height) between 1.8 and $2.8 \mathrm{~cm}$ were randomly selected; this was done in order to avoid differences in age of substrate. Epiphytic bryophyte vegetation was censused and biomass harvested. Species were collected and identified with help from specialists and temporarily stored at the herbarium of the
University of Amsterdam (AMD). Bryomass samples were sorted at species level and dried for $24 \mathrm{hr}$ at $70^{\circ} \mathrm{C}$ in order to determine dry weight.

On five small oak stems 44 epiphytic bryophyte species were recorded in 18 families, equally distributed over mosses and hepatics (Tables 1 and 2). A total of 24 were identified to species level (54.5\%), whereas the remaining collections were recognized as morphospecies and determined at genus level. Fig. 1 shows the species/area curve for cumulative numbers of species and samples on basis of results from ten random permutations of possible sample sequences. A TWINSPAN analysis (Hill 1979) did not reveal a particular subdivision into two distinct bryophyte communities (Van Dunné 1993). This suggests a high homogeneity among samples which probably belong to one single epiphytic bryophyte community. Sørensen's similarity coefficients, ranging from 0.51 to 0.73 , also indicate that samples were similar in species composition, and consequently, that the sampling strategy was adequate for the purpose of this study.

Average dry weight values of bryomass in samples, as well as for moss and liverwort portions separately are given in Table 2 . Total dry weight ranges from 1.02 to $6.02 \mathrm{~g}$ per sample. Biomass per unit area ranged from 0.13 to $0.68 \mathrm{~g} / \mathrm{dm} 2$. Mosses make up 54 to $99 \%$ of the total bryomass per sample. Fig. 2 shows the biomass-diversity relation as expressed in the average dry weight and ranking of the 21 most important species. Frequency and biomass per unit area are positively correlated for all individual samples (Pearson's correlation coeficient is 0.718 , $\mathrm{P}<0.001)$. No significant correlation was found for biomass per unit area and species number of individual samples.

The biomass of mosses outweighs the value for liverworts in all five samples. This is indicative for a relatively dry forest, as humid 


\section{TABLE 1}

List of epiphytic bryophyte species recorded on five small-sized Quercus copeyensis Müll. host trees in a mature montane cloud forest, San Gerardo de Dota, Costa Rica. Collection numbers of the first author correspond to botanical specimens temporarily stored in the herbarium of the University of Amsterdam (AMD). Authors of plant names are given following Brummit \& Powell (1992)

\section{LIVERWORTS}

\section{HERBERTACEAE}

Herbertus sp. 1

JUBULACEAE

Frullania brasiliensis Raddi sensu lato

Frullania convoluta Lindenb. \& Hampe

Frullania cuencencis Taylor

LEJEUNEACEAE

Amphilejeunea patellifera (Spruce)

R.M.Schust.

Anoplolejeunea conferta (Meissn.) Schiffn.

Cheilolejeunea rigidula (Mont. \& Nees)

R.M.Schust.

Lejeunea sensu lato

Lejeunea sp. 1

Lejeunea sp. 2

Microlejeunea bullata (Taylor) Steph. METZGERIACEAE

Metzgeria decipiens (Mass.) Schiffn.

\section{PLAGIOCHILACEAE}

Plagiochila bidens sensu lato

Plagiochila echinella Gottsche

Plagiochila guilleminiana Nees \& Mont.

Plagiochila sp. 17

Plagiochila sp. 18

PORELLACEAE

Porella sp. 1

RADULACEAE

Radula sp. 1

TRICHOCOLEACEAE

Trichocolea tomentosa (Sw.) Gotsche UNKNOWN

Coll. Van Dunné 116

Coll. Van Dunné 223

\section{MOSSES}

\section{HYPNACEAE}

Chryso-hypnum diminutivum (Hampe) Buck

Chryso-hypnum sp. 1

Coll. Van Dunné 091

LEUCODONTACEAE

Leucodon curvirostris Hampe

METEORIACEAE

Meteorium illecebrum Mitt.

Pilotrichella flexilis (Hedw.) Ångstr.

Squamidium nigricans (Hook.) Broth.

MNIACEAE

Plagiomnium rhynchophorum (Hook.)

T.J.Kop.

\section{NECKERACEAE}

Neckera chilensis Schimp. ex Mont.

Porotrichodendron superbum (Taylor) Broth.

Rigodium sp. 1

PTEROBRYACEAE

Pireella sp. 1

PRIONODONTACEAE

Prionodon densus (Hedw.) Müll.Hal.

Prionodon lycopodioides Hampe

SEMATOPHYLLACEAE

cf. Pterogonidium pulchellum (Hook.)

Müll.Hal.

Sematophyllum sp. 1

ORTHOTRICHACEAE

Zygodon peruvians Sull.

Zygodon reinwardtii (Hornsch.) Braun in Bruch

Zygodon sp. 3

Zygodon sp. 4

UNKNOWN

Coll. Van Dunné 085

Coll. Van Dunné 350 


\section{TABLE 2}

Some structural parameters of five small-sized Quercus copeyensis Müll. host trees and the epiphytic bryophyte vegetation they support in a mature montane cloud forest, San Gerardo de Dota, Costa Rica. Averages for $n=5$ and standard errors are given

\begin{tabular}{|c|c|c|c|c|c|c|}
\hline Sampled host tree & $S 1$ & S 2 & S 3 & S 4 & S 5 & $X+$ S.E. \\
\hline \multicolumn{7}{|l|}{ Tree size } \\
\hline Tree height (m) & 3.0 & 2.8 & 3.0 & 3.4 & 2.2 & $2.88+0.20$ \\
\hline $\mathrm{DBH}(\mathrm{cm})$ & 2.0 & 2.8 & 2.8 & 2.5 & 1.8 & $2.38+0.21$ \\
\hline Sample area $(\mathrm{dm} 2)$ & 6.28 & 8.79 & 8.79 & 7.85 & 5.65 & $7.47+0.65$ \\
\hline \multicolumn{7}{|l|}{ Species richness } \\
\hline Mosses & 10 & 10 & 9 & 11 & 12 & $10.40+0.51$ \\
\hline Liverworts & 14 & 9 & 11 & 16 & 16 & $13.20+1.39$ \\
\hline Total Bryophytes & 24 & 19 & 20 & 27 & 28 & $23.60+1.81$ \\
\hline \multicolumn{7}{|l|}{ Abs. Biomass (g) } \\
\hline Mosses & 2.43 & 5.96 & 1.56 & 0.55 & 3.44 & $2.79+0.93$ \\
\hline Liverworts & 1.09 & 0.06 & 0.53 & 0.48 & 0.18 & $0.47+0.18$ \\
\hline Total Bryophytes & 3.52 & 6.02 & 2.09 & 1.02 & 3.62 & $3.25+0.84$ \\
\hline \multicolumn{7}{|l|}{ Rel. Biomass (g/dm2) } \\
\hline Mosses & 0.39 & 0.68 & 0.18 & 0.07 & 0.61 & $0.39+0.12$ \\
\hline Liverworts & 0.17 & 0.01 & 0.06 & 0.06 & 0.03 & $0.07+0.03$ \\
\hline Total Bryophytes & 0.56 & 0.68 & 0.24 & 0.13 & 0.64 & $0.45+0.11$ \\
\hline
\end{tabular}

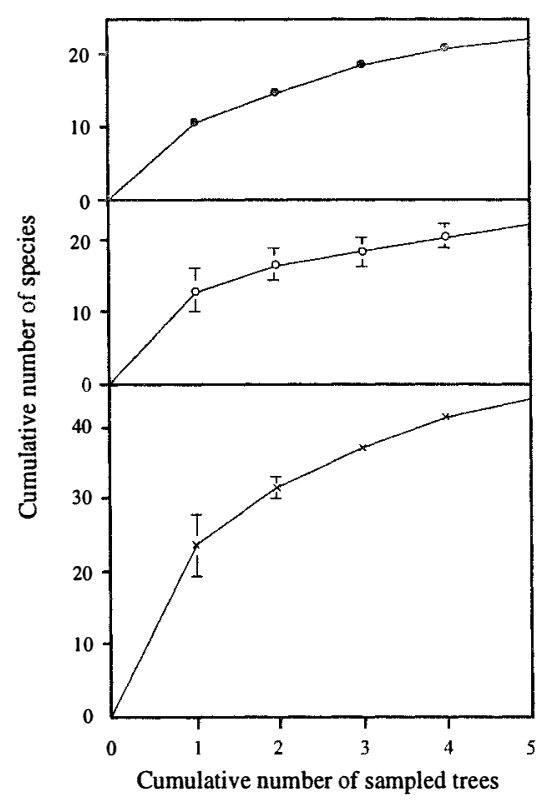

Fig. 1. Species/area relations showing cumulative number of epiphytic bryophyte species and cumulative number of sampled Quercus copeyensis tree stems in a mature montane cloud forest, San Gerardo de Dota, Costa Rica. Graphs represent mosses (top) and liverworts (centre) seperately, and total number of bryophytes (bottom). Plotted data in the diagram represent ten permutations of possible sequences in which sampled tree stems may be plotted. Plotted values correspond to numbers of species (mean + 1 S.E.) and perhumid conditions in upper montane cloud forest interiors are expressed by a high diversity and dominance of liverworts (Gradstein et al. 1989). The concave biomassdiversity pattern as presented in Fig. 2 is in accordance with the dominance-diversity theory of epiphytic bryophyte communities ( $c f$. Wolf 1993a). This concave trend can be attributed to the Principle of Priority, which holds that the first species to colonise a site has the biggest chance to form pure patches through growth and vegetative reproduction, excluding new arrivals (Benzing 1981, Wolf 1993a and 1995). Species suitable to grow in a particular environment-i.e. mature forest and west-facing bark of oak tree stems in this study-would have an equal chance to settle, develop and attain high cover or biomass values.

The correlation which was found between biomass and frequency of species in our five samples is in contrast with calculations based on Wolf's (1993b) relative frequency and average cover data of tree base communities. This discrepancy is probably due to a difference in 


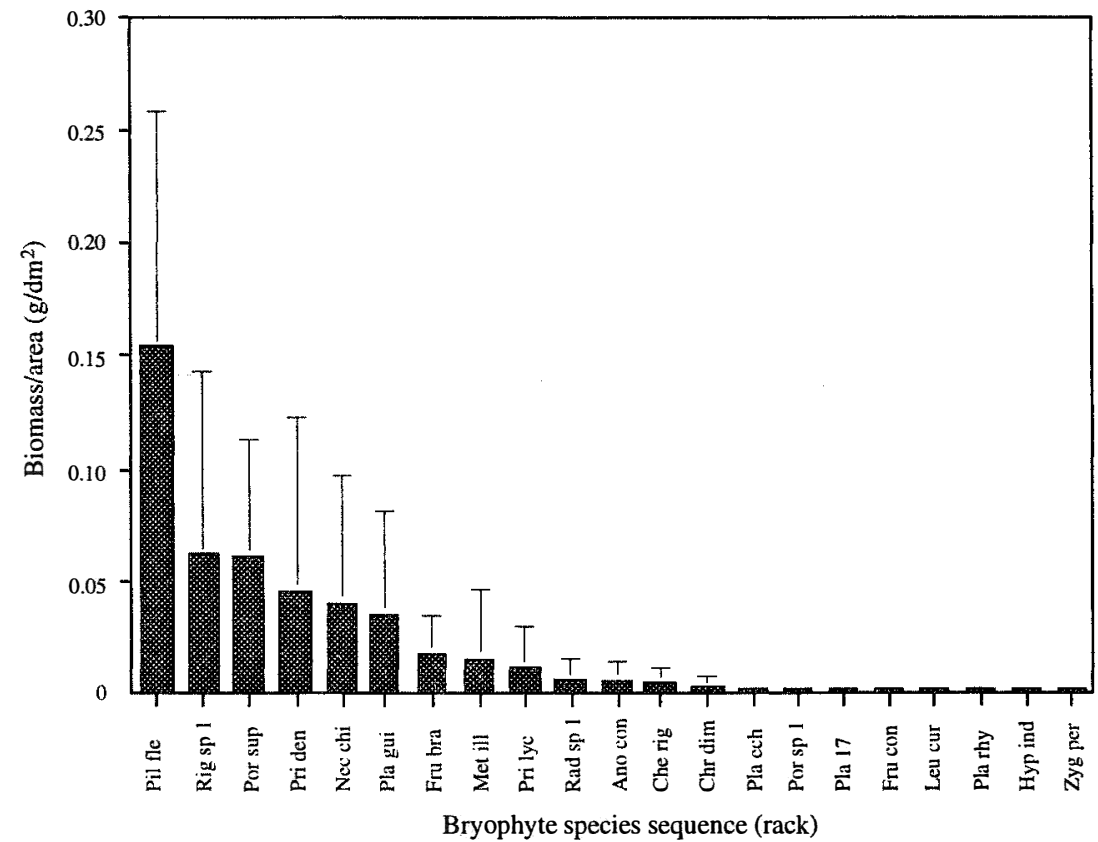

Fig. 2. Biomass-diversity diagram for epiphytic bryophytes in a mature montane cloud forest, San Gerardo de Dota, Costa Rica. Bryophyte species are ranked from high to low biomass per unit area $(\mathrm{g} / \mathrm{dm} 2) \mathrm{vs}$. their biomass per unit area (Y-axis). Data represent mean +1 S.E. where $n=5$, with $n$ is the number of sampled oak trees. The species on the $X$-axis have been abbreviated; their full names are: Pilotrichella flexilis (Hedw.) Ångstr., Rigodium sp 1, Porotrichodendron superbum (Taylor) Broth., Prionodon densus (Hedw.) Müll.Hal., Neckera Chilensis Schimp. ex Mont., Plagiochilla guilleminiana Nees \& Mont., Frullania brasiliensis Raddi, Meteorium illecebrum Mitt., Prionodon lycopodioides Hampe, Radula sp. 1, Anoplolejeunea conferta (Meissn.) Schiffn., Cheilolejeunea rigidula (Mont. \& Nees) R.M.Schust., Chryso-hypno diminutivum (Hampe) Buck, Plagiochilla echinella Gottsche, Porella sp. 1, Plagiochilla sp. 17, Frullania convoluta Lindenb. \& Hamp., Leucodon curvirostris Hampe, Plagiomnium rhynchophorum (Hook) T.J. Kop., Hypnaceae indet., and Zygodon peruvianum Sull.

sampling strategy. Wolf's sampling method was directed at recording total diversity, structure and species composition of a large number of representative bryophyte communities and included different host tree species, positions within trees and sample sizes.

In a nearby $30 \mathrm{yr}$ old secondary oak forest Schillemans (1995) observed on five similar small-sized $Q$. copeyensis oak stems only 3 omnipresent species out of a total of 39 bryophytes (11 mosses, 28 liverworts), all three being liverworts: Frullania brasiliensis Raddi, Metzgeria decipiens (Mass.) Schiffn. and Radula sp. 1. These species were also recorded in this study's mature forest, but with relatively low biomass per unit area values.
Unfortunately, Schillemans (1995) did not provide biomass data for his species' records.

Status and rate of recovery of epiphytic bryophyte communities on trees in successional forests may be a key measure for the level of forest recovery at a certain moment, especially when the importance of epiphytes for water and nutrient retention is taken into account. As an example serves the moss species Pilotrichella flexilis which appeared to have the highest dry weight per sample on small-sized oak stems in mature forest. This pendant species which is commercially harvested for use in Christmas stables (M.I. Morales and G. Dauphin, pers. com.) may indicate a high level of disturbance when found in low quantities. 
Given the importance of epiphytic bryophytes for forest hydrology (Pócs 1974, 1980, Nadkarni 1986, Veneklaas et al. 1990) and the results of the present study-i.e. the fact that epiphytic bryomass in the forest's understory appears to be determined by relatively few species -, more detailed information about the structure of the epiphytic biomass in tropical forests, and particularly montane cloud forests, is urgently needed. Conservation and wise management of these forests requires baseline information about species of possible key importance to maintaining hydrological properties of the forest such as rain fall interception and water retention.

In the present study $90 \%$ of total bryomass per unit area can be attributed to only six species, namely Pilotrichella flexilis (Hedw.) Ångstr., Rigodium sp. 1, Porotrichodendron superbum (Taylor) Broth., Prionodon densus (Hedw.) Müll. Hal., Neckera chilensis Schimp ex Mont. and Plagiochila guilleminiana Mont. (Fig. 2). We assume that these species contribute largely to stem flow regulation on small understorey trees such as saplings, as they are able to retain water and nutrients. Their proportion of the total bryomass on small-sized oak stems may be an indication of their key importance to the hydrological functioning of tropical montane oak dominated cloud forests. Further study is needed to support this theory.

\section{ACKNOWLEDGEMENTS}

We are indebted to A.M. Cleef for he opportunity to conduct the study. H.J.F.V.D. was supported by a travel grant of the Hugo de Vries Laboratory. M.K. was supported by a research fellowship (grant W 84-331) awarded by the WOTRO Foundation of the Netherlands Organization for Scientific Research (NWO). P. Sánchez and M. Valerio of the Museo Nacional, and M.I. Morales of the University of Costa Rica generously offered herbarium facilities. We acknowledge J.H.D. Wolf, G.B.A. van Reenen, S.R. Gradstein, D.H. Norris, D. Vitt and J. Enroth for assistance with bryophyte species identification and M.E. Juárez for cooperation during fieldwork. The friendly hospitality of the Monge family in San Gerardo de Dota is very much appreciated.

\section{REFERENCES}

Barkman, J.J. 1958. Phytosociology and ecology of cryptogamic epiphytes. Van Gorcum, Assen, the Netherlands.

Benzing, D.H. 1981. Bark surfaces and the origin and maintenance of diversity among angiosperm epiphytes: a hypothesis. Selbyana 5: 248-255.

Brummit, R.K. \& C.E. Powell (eds.) 1992. Authors of plant names. Royal Botanical Gardens, London. 732 p.

Coxson, D.S. 1990. Nutrient release from epiphytic bryophytes in a tropical montane rain forest (Guadeloupe). Can. J. Bot. 69: 2122-2129.

Frahm, J.P. 1987. Which factors control the growth of epiphytic bryophytes in tropical rain forests? Symp. Biol. Hung. 35: 639-648.

Gradstein, S.R. 1992. Threatened bryophytes of the neotropical rain forest: a status report. Trop. Bryol. 6: 83-9́3.

Gradstein, S.R., G.B.A. van Reenen \& D. Griffin. 1989. Species richness and origin of the bryophyte flora of the Colombian Andes. Acta Bot. Neerl. 38(4): 439-448.

Gradstein, S.R., D. Montfoort \& J.H.C. Cornelissen. 1990. Species richness and phytogeography of the bryophyte flora of the Guianas, with special reference to the lowland forest. Trop. Bryol. 2: 117-126.

Hill, M.O. 1979. TWINSPAN. A FORTRAN program for arranging multivariate data in an ordered two-way table by classification of the individuals and attributes. Cornell University. Ithaca, New York.

Hofstede, R.G.M., J.H.D. Wolf \& D.H. Benzing. 1993 Epiphytic biomass and nutrient status of a Colombian upper montane rain forest. Selbyana 14: 37-45.

Johansson, D. 1974: Ecology of vascular epiphytes in West African rain forests. Acta Phytogeogr. Suec. 59: 1-136 
Kappelle, M. 1992. Structural and floristic differences between wet Atlantic and moist Pacific montane Myrsine-Quercus forests in Costa Rica, p. 61-70. In H. Balslev \& J.L. Luteyn (eds.). Páramo, an Andean Ecosystem under Human Influence. Academic. London, UK.

Kappelle, M. 1996. Los Bosques de Roble (Quercus) de la Cordillera de Talamanca, Costa Rica: Biodiversidad, Ecologia, Conservación y Desarrollo. University of Amsterdam/ Instituto Nacional de Biodiversidad. Amsterdam/Santo Domingo de Heredia. 319 p.

Nadkarni, N.M. 1984. Epiphyte biomass and nutrient capital of a neotropical elfin forest. Biotropica 16: 249-256.

Nadkarni, N.M. 1986. The nutritional effects of epiphytes on host trees with special reference to alternation of precipitation chemistry. Selbyana 9: 44-51.

Pócs, T. 1974. The role of the epiphytic vegetation in the water balance and humus production of the rain forests of the Uluguru Mountains, East Africa. Boissiera 24: 499-503.

Pócs, T. 1980. The epiphytic biomass and its effect on the water balance of two rain forest types in the Uluguru Mountains (Tanzania, East Africa). Acta Bot. Acad. Scient. Hung., 26(1-2): 143-167.

Schillemans, M. 1995. Bryophyte diversity on Quercus copeyensis treelets in a secondary montane rainforest, during the wet season, in the Cordillera de Talamanca, Costa Rica. M.Sc. Thesis. Report 298. University of Amsterdam. Amsterdam.

Van Dunné, H.J.F. 1993. Bryophyte diversity on Quercus copeyensis Muell. treelets in an undisturbed mature upper montane rain forest during the wet season in the Cordillera de Talamanca, Costa Rica. M.Sc. Thesis. Report 299. University of Amsterdam. Amsterdam.

Veneklaas, E. \& . R. van Ek. 1990. Rainfall interception in two tropical montane rain forests, Colombia. Hydrol. Proc. 4: 311-326.

Veneklaas, E., R. Zagt, A. van Leerdam, R. van Ek, G. Broekhoven \& M. van Genderen. 1990. Hydrological properties of the epiphyte mass of a montane tropical rain forest, Colombia. Vegetatio 89: 183-192.

Wolf, J.H.D. 1993a. Epiphyte communities of tropical montane rain forests in the Northern Andes. I. Lower montane communities. Phytocoenol. 22(1): 1-52.

Wolf, J.H.D. 1993b. Epiphyte communities of tropical montane rain forests in the Northern Andes. II. Upper montane communities. Phytocoenol. 22: 53-103.

Wolf, J.H.D. 1995. Non-vascular epiphyte diversity patterns in the canopy of an upper montane rain forest $(2550-3670 \mathrm{~m})$, Central Cordillera, Colombia. Selbyana 16: 185-195. 